\title{
A BRITISH MERCHANT IN TURKEY: FREEMAN OF THE LEVANT COMPANY AND CONSUL, DONALD SANDISON AT BURSA, 1795-1868
}

\author{
Emine Zeytinli \\ Dr., University of Leicester School of History
}

\begin{abstract}
Donald Sandison was a British merchant who was based in Istanbul, from where he ran his business beginning with the second decade of the nineteenth century. He established business partnerships and became a member of the British Levant Company as well as a consul. He was the first British consul to Bursa, between 1838 and 1868. This bibliographic study focuses on Sandison, an overseas British citizen in Istanbul, as both a merchant and a consul. The study includes a wealth of information from national archives in Great Britain and Turkey, genealogical search, and nineteenth-century British newspapers.
\end{abstract}

Keywords: Donald Sandison, British Merchant, Levant Company, Consul, Bursa, Trade.

$\ddot{O} \mathbf{z}$

\section{TÜRKIYE'DE BİR INGGILIZ TÜCCAR: LEVANT KUMPANYASI ÜYESI VE BURSA KONSOLOSU, DONALD SANDISON, 1795-1868}

Donald Sandison on dokuzuncu yüzyılın başında İstanbul'a yerleşen ve ticari faaliyetlerini bu şehirden yürüten İngiliz bir tüccardır. Sandison ticari ortaklıklar geliștirmiș, İngiliz Levant Kumpanyası üyesi ve sonrasında konsolos olmuştur. 1838 ile 1868 yılları arasında Bursa'da görev yapan ilk İngiliz konsolosudur. Bu biyografik çalışma İstanbul'da tüccar ve ardından ticari faaliyetlerine ek olarak Bursa'da konsolos olan bir İngiliz'in hayatını konu almaktadır. Çalışma için Büyük Britanya ve Tükiye ulusal arşivleri, soy ağacı araştırmalarının yürütüldüğü çeşitli arşivler ve on dokuzuncu yüzyıl İngiliz gazeteleri kullanılmıştır.

Anahtar Kelimeler: Donald Sandison, İngiliz Tüccar, Levant Kumpanyası, Konsolos, Bursa, Ticaret.

This article is a revised and expanded version of a paper entitled "A British Merchant in Turkey: Freeman of the Levant Company and Consul, Donald Sandison at Bursa, 1795-1868" presented at Economic History Society Annual Conference, Keele University, UK, 6-8 April 2018.

Sorumlu yazar/ Corresponding author: Emine Zeytinli, ez68@leicester.ac.uk Geliş Tarihi/Submitted: 23.05.2018 Kabul Tarihi/Accepted: 19.11.2018

DOI: 10.26650 /TurkJHist.2018.426566

Cite this article as: Emine Zeytinli, "A British Merchant in Turkey: Freeman of the Levant Company and Consul, Donald Sandison at Bursa, 1795-1868", Turk J Hist, issue 68 (2018), p.31-56. 


\section{EMINE ZEYTINLI}

\section{Introduction}

European countries started having close commercial links with the Ottoman Empire from the fifteenth century via their merchants. Obtaining concessions was the common way of establishing economic as well as diplomatic relations. Increases in the volume of trade and the size of the commodity market necessitated acquired positions and roles in certain trade hubs of the empire in order to establish and facilitate trade networks.

Residing in the Ottoman port and trading cities was a common practice of European merchants in order to carry out trading activities. Donald Sandison was one of these merchants who arrived in Istanbul at the beginning of the nineteenth century and became a privileged member of the Levant Company. He later became consul of Bursa.

When European countries adopted protectionist economic policies from the beginning of the nineteenth century, the Ottoman Empire offered a promising market for continental goods. Therefore, the significance of the whole of the Middle East, as well as the Balkan regions, increased and became clear, strong and effective. The number of British merchants and investors, as well as consuls and vice-consuls, increased in this period.

From the 1830s the British consular presence increased in the Ottoman territories after the abolition of the British Levant Company; British consuls represented in more cities such as Antalya, Batumi, Belgrade, Yas (Jassy), Kayseri (Caesarea), Samsun, Tarsus, Varna etc. Donald Sandison was appointed as consul in 1838 in the city of Bursa where silk production dominated the city's economy. This was the same year (1838) that the British and Ottoman Empires signed the Anglo-Ottoman Commercial Conventio ${ }^{1}$ which allowed free trade between the two nations. Consuls were agents or commissioners, and generally merchants, responsible for observing the trade capacity in the city or region, comparing the volume of its trade with other trading nations in the region and reporting trade statistics as well as providing other reports concerning trade and reporting to the British foreign ministry. Consuls were responsible for some practical matters, but their main responsibility was to maintain and develop trade with the empire.

The second stage of Sandison's professional life had a close connection with the Anglo-Ottoman Commercial Convention of 1838. This convention gave certain

It is also called as Balta Limanı Commercial Convention. Hereafter as Anglo-Ottoman Commercial Convention of 1838 as in the original English document. 
privileges to British merchants and goods were allowed to be transported freely in Ottoman dominions. British commercial interests into the inland centres resulted in the appointment of its own consuls. Sandison was appointed salaried consul for Bursa with the liberty to trade after operating as a merchant for more than two decades. He was the first British consul at Bursa, one of the industrial and leading cities in textile manufacturing, between 1838 and 1868 .

This article aims to contribute the current research literature on the commercial relations between the Ottoman Empire and Western countries, namely, British involvement and how certain parts of the Ottoman economy were affected or developed. Previous researches carried out and analysed the intervention of Western mercantilist communities in some well-known port cities such as Istanbul, Salonica and Izmir where British consuls were initially appointed before the nineteenth century. Consular posts were established in inland cities with the Commercial Convention of 1838 and Bursa was one of these. However, for Bursa, appointed British consuls, their careers and status in domestic and international trade have been insufficiently researched.

This article analyses Donald Sandison's commercial operations in Istanbul, his connections, marriage, family and his consular post in Bursa. The sources used in this research are Sandisons's correspondence with the Consul-General, as well as the British Embassy at Istanbul and private letters. Documents provide little evidence and few details of his career before the 1820s; however, correspondences with British Foreign Office and officials are available prior to and during his consular post. Ottoman archival documents were also analysed both for economic activities and the family history of Donald Sandison.

\section{Early Years and Commercial Operations of Donald Sandison}

Donald Sandison was a Scottish merchant who moved to Istanbul ${ }^{2}$, and was mentioned by travellers to the city. An American missionary and long-time

2 He was born as the son of James Sandison, a merchant in Wick, on November 1, 1795 (National Records of Scotland, Old Parish Registers Births 043/30136 Wick). This church register of baptism is confirmed with the certificate of his marriage that cites him as coming from the town of Wick, Caithness, Scotland (dated January 24, 1824, The Anglican Chaplaincy, The British Consulate of Istanbul, Register of Birth, Deaths and Marriages, from 1757 to 1840, page not availab1e). His consulship was advertised in a local newspaper where he was named as the third son of the late James Sandison, “...our talented townsman, Donald Sandison, Esq., has been appointed her Majesty's Consul at Broussa. Mr. Sandison, who is the third son of the late Mr James Sandison of Wick, has been for a considerable number of years resident in the East, and is, from his abilities, knowledge, and experience in business, eminently well qualified to discharge the duties entrusted to him..." (John O’Groat Journal, December 7, 1838, col. 23. 
resident in Istanbul, Cyrus Hamlin, called him 'the Scottish nobleman'3 and English travellers, Sir Edwin Pears and Charles MacFarlane, mentioned Sandison as coming from a Scottish family while writing about his son, Alfred John Sandison ${ }^{4}$. Before moving to Istanbul, Sandison must have disembarked at Izmir and spent some time there as his brother, James Sandison, was a merchant in Izmir and died of fever there in $1828^{5}$. Hyde Henry Clarke ${ }^{6}$ in 1860 mentions that in Izmir there were about half a dozen merchants licensed to trade beside the members of the British Levant Company. They were the sons or apprentices of freemen ${ }^{7}$. Both Donald Sandison's privileged position in the Levant Company and the fact that his brother was a merchant in Izmir are factors that suggest that their father might

3 Cyrus Hamlin, Among the Turks, (New York, American Tract Society, 1877), 250-251. According to the church register the baptism of Donald Sandison was witnessed by a Baillie (a civic officer of the local government in Scotland) named Robert Couro (?). This refers to the family of Sandison having a certain status in society as a member of the aristocracy.

4 "Sir Alfred Sandison possessed the same kind of fullness of knowledge of Turkish. The son of Scotsman, he had been born in Turkey...", Sir Edwin Pears, Forty Years in Constantinople, (London, Herbert Jenkins Limited, 1915), 138. Sir Alfred Sandison was knight diplomat; oriental secretary in Istanbul, Sir Alexander Telford Waugh, dragoman at Istanbul in 1901, Consul-General in 1920, described him as "too easy-going for the work in hand", "sport-loving character, very popular with the Turks", "Sir Alfred Sandison, who had been born in Turkey and spoke Turkish remarkable (sic) well. He had been employer (sic) as interpreter with the army during the Crimean War, and was then taken on at the Embassy to succeed the old race of Levantine interpreters, many of them of Genoese or Venetian family..." Sir Alexander Telford Waugh, Turkey, Yesterday, To-Day, and To-Morrow, (London, Chapman and Hall's, 1930), 27, 37. A number of newspapers such as the Manchester Courier and Lancashire General Advertiser, The Western Times, Citizen and The Nottingham Evening Post published his obituary mentioning “... The deceased gentleman was a well-known figure in Istanbul diplomatic and official society... Sir Alfred Sandison's diplomatic abilities were of a high order, and he showed much tact on handling many delicate and important matters. He was persona gratissima in the Turkish official world, and the Sultan held him in the highest esteem, "Manchester Courier and Lancashire General Advertiser”, December 31, 1906, Issue 15646, Manchester, 7.

5 “...During the summer of last year two of my countrymen and friends (Mr. John Wilkinson and Mr. James Sandison) fell victims to the detestable Smyrna fever. They died within a few days of each other, after a very short illness." Charles MacFarlane, Constantinople in 1828, A Residence of Sixteen Months in the Turkish Capital and Provinces: with an Account of the Present State of the Naval and Military Power, and of the Resources of the Ottoman Empire, (London, Saunders and Otley. 1829), 22); James Sandison, buried September 28, 1828, Smyrna Anglican Chaplaincy (Baptism, Marriage and Burial Records of the British Chapel, Smyrna-Turkey 1800-1944).

6 Agent of the Izmir-Aydin Railway Company and later vice president of the Imperial Cotton Commission Company. For a detailed assessment see http://www.levantineheritage.com/pdf/Hyde-Clarke-by-D-Wilson-2015.pdf.

7 Hyde Henry Clarke, "The History of the British Colony at Smyrna”, The Levant Herald, 1860, ([British Library 10077.a.11) 3. 


\section{DONALD SANDISON}

have been a licensed merchant in the Levant and membership of the Company passed to his descendants.

In Constantine Ionides Ipliktsis ${ }^{8}$ by Timotheos Catsiyannis, Sandison is described as "an English trader, who was operating in Constantinople from a textile shop." However, Ipliktsis's other biographer, Anastasios Goudas wrote, at that time there was a trader in Constantinople of British nationality, called Sandison, who gladly offered protection through the British Embassy to the persecuted subjects of the Sultan. Ipliktzis immediately attached himself to this Englishman and started acting as his broker.

Half joking, he recounted, years later, 'not only did I act as a broker but also I was a 'town crier', in order to please my partner and protector."'

The partnership between Sandison and Ipliktsis did not last for long; Ipliktsis was too good a businessman to be an employee:

...Constantine began as a simple clerk and when he had saved some money he started working for himself again. It was then that he decided on the greatest commercial venture of his life; To come to England. To the Metropolis of the World's trade ${ }^{10}$.

Ipliktsis had learnt that big money was only earned when working for himself. As he recounts, "when I earned fifty rupees (gold Turkish coin, worth about half a gold five pound), I said praised be to God. At last I am reentering the arena of trading." Goudas wrote that soon Ipliktsis "earned so much money as a broker for Sandison, that it became possible for him to start trading on his own account." 11

8 Constantine Ipliktsis was a textile merchant in Istanbul and moved to London before 1820 presumably. Carried out his business there until he died. He adopted the last name of "Ionides".

9 Anastasios N. Goudas, Vioi paralliloi ton eps tis Anagenniseos tis Ellados diaprepsanton andron, Vol. III, (Athens, Plots I Emporion, 1970), 5-6.

10 Timotheos Catsiyannis, Contantine Ionidis Ipliktsis, 1775-1852 and The Ionidi Family, (London, Privately published, 1988), 5-6. Ipliktsis biographer, Catsiyannis, wrote: “...His specialty was the textile trade. In the course of execution of this trade Constantine soon understood that among the people who conducted the textile business, the retailers, one of whom he was, made very little profit, while the intermediaries, who safely remained at the offices, with little hard work and no financial risk, enjoyed for larger profits. So it occurred him to cut out this expensive stage and send his own people to England (sic) purchase textile directly from the factories... The were commissioned to come to England and buy the textiles from the mills. The result was a fantastic increase in profit...", Catsiyannis, Contantine Ionidis Ipliktsis, 8-9.

11 Goudas, Vioi paralliloi, 6. 
Donald Sandison's daughter, Fanny Janet Blunt, wrote that her father originally went to Turkey as the representative of the East India Company at the beginning of the nineteenth century. His business flourished until it was destroyed during Janissary Revolt ${ }^{12}$ and he then became the British Consul at Bursa. Janet Blunt also wrote that

During this rebellion my father's house of business, like many others, was not only looted and burnt down but his business was so thoroughly disorganised that it could not be built up again in Constantinople ${ }^{13}$.

These comments do not fit in with the known dates concerning Sandison's career. Abolition of the crops was in 1826 and Sandison become consul in Bursa in 1838 .

In addition to being a representative of the East India Company, Sandison also became a member of the exclusive Levant Company in July 1817 (registered in January 1818) ${ }^{14}$. Hyde Henry Clarke confirms this date and says “....in 1817, Jasper Chasseaud was admitted and, in the same year, Donald Sandison." ${ }^{15}$ However, 20 merchants were accepted as members of the company, while Clarke mentioned only two of them. Clarke also wrote that membership could only be obtained in England; a freeman was admitted by the general court in London and the new member paid a certain fee. However, in later years Englishmen residing in the Levant could take the oath before the authorities of the British Levant Company by paying a fee of twenty pounds ${ }^{16}$.

\section{Family Life}

Sandison's business as a merchant in Istanbul probably shaped his family life. In 1824 he married Mary Zohrab ${ }^{17}$, the daughter of Constantine Zohrab, a merchant and partner of John Cartwright who became the British Consul-General in Istan-

12 The revolt was resulted with the abolition of the corps which is so called Vaka-i Hayriye (the Auspicious Event).

13 Fanny Janet Blunt, My Reminiscences, (London, John Murray, 1918), vii.

14 The National Archives, State Papers (henceforth “SP”), 105/211, Register of orders made by the General Court of the Levant Company, 1734-1818; SP, 105/333, 1744-1824.

15 Clarke, "The History of the British Colony at Smyrna", 1860, 7.

16 Ibid, 3.

17 They married on January 17, 1824 in the Chapel of the British Embassy at Istanbul, in the presence of Mary Zohrab's father, Constantine Zohrab, and the British Consul-General, John Cartwright (The Anglican Chaplaincy, Istanbul, page not available). 


\section{DONALD SANDISON}

bul in $1817^{18}$. This contact must have made a positive contribution to his business, although Sandison was already a member of the Levant Company before he got married and one must take into consideration the fact that he was fluent in French, Italian, Greek and had a working knowledge of Turkish ${ }^{19}$.

Fanny Janet Blunt wrote about her family that:

My father married Miss Mary Zohrab, whose family had originally come from Persia. There were two branches of this princely house who had quitted Sistan in Persia during some revolutionary upheaval. One branch settled in Europe, the other, my grandfather's branch, settled in Turkey ${ }^{20}$.

Sandison lived with his family at Tarabya on the Bosphorus until his consular post at Bursa. He had five daughters and a son ${ }^{21}$, all born at Tarabya ${ }^{22}$, the suburb of Istanbul where diplomatic representatives preferred to live ${ }^{23}$.

18 Before he was appointed as Consul-General at Istanbul, John Cartwright, was cancellier at Istanbul between 1799-1801, consul at Patras between 1815-1817, Parliamentary Papers, Report from the Select Committee on Consular Establishment; Together with the Minutes of Evidence, and Appendix, August 22, 1835, Vol. 26, 126.

19 In response to queries by the Foreign Office, Donald Sandison answered a question regarding his fluency and ease of the language(s) as follows: "I can as to French and Italian, also speak and read the medium (sic) Greek with fluency, and the Turkish serviceably for the transaction of public business.", The National Archives, Foreign Office Papers (henceforth "FO"), 78/570, January 31, 1844, 186; FO, 78/868, 1851, 178.

20 Blunt, My Reminiscences, vii-viii.

21 Five of his children-Sophia, born in April 1826, Anne, born in September 1827, Maria Matilda, born in July 1831, Alfred John, born in April 1835, and Fanny Janet, born in July 1838 - were registered to the parish, The Anglican Chaplaincy, 1-2). One of his daughters, Nancy, was a victim of the epidemic of Asiatic cholera in 185, Blunt, My Reminiscences, 19). Sandison's first son, James Robert Sandison (born in September 1829), was registered at the Chaplaincy of Smyrna. He died eleven months later and was buried at Izmir in July 1830, Smyrna Anglican Chaplaincy, Baptism, Marriage and Burial Records of the British Chapel, Smyrna-Turkey 1800-1944.

22 Donald Sandison's first son, James Robert Sandison was born and died a year later in Izmir according to the registers at Izmir. Therefore, Donald Sandison must have lived in Izmir for the period 1827-1831 as his second and third daughters (born in 1827 and 1831 respectively) were registered at the chaplaincy of Istanbul. This is thought to be due to losing business contacts in Istanbul as a number of local merchants started to have direct trade with European counterparts, abolishing of military corps, Janissaries that Donald Sandison was in commercial contact with his brother, James Sandison.

23 Blunt, My Reminiscences, 1. 
Fanny Janet Blunt also wrote that she was born at Therapia, that beautiful suburb of Constantinople on the shores of the Bosphorus where the members of the Diplomatic Corps lived. Our house stood on the hill, and from the long terrace which ran down one side of it we had glorious views over the Black Sea, which was some two or three miles from $u^{24}$.

\section{Consular Establishment, Position and Services of Consulates in British}

\section{Trade}

The term consul is described as "...representatives of the interests of foreign states in Islamic countries..." ${ }^{25}$ The consulate system in Ottoman provinces started with establishing agents in some major port cities on the Eastern Mediterranean and Aegean seas. Consuls, who were generally merchants, resided in these cities first for their own commercial activities. After the British Levant Company was dissolved, consuls became depended on by the state and the number of posts increased further to include inland provinces with the aim of encouraging British trade in the Ottoman territories ${ }^{26}$.

The Anglo-Ottoman Commercial Convention ${ }^{27}$ increased consular services in the Ottoman dominions and shows the British commercial and political interests in the Eastern Mediterranean. Consuls aimed to secure commercial expansion in the Levant and the Near East; they dealt with commercial challenges beside consular-related matters.

Consular post were generally analysed from a diplomatic and political point of view as they influenced and shaped British foreign policy. However, since the sixteenth century, consular posts had generally been filled by those individuals with a mercantilist background who had gained valuable knowledge of the local econom-

24 Fanny Janet Blunt also described her childhood at Bursa as follows: "My childhood was spent almost entirely at Brussa, and a very happy childhood it was. My brother and I were great companions and had many adventures in the country together. We used to have lessons with the children of the American missionary who lived nearby, and the daily interchange of ideas with a family brought up under such different hereditary influences to ours was an education in itself...", Ibid, 8 .

25 For a detailed assessment see: The Encyclopaedia of Islam, eds. B. Lewis, CH. Pellat, J. Schacht, Vol. II, E.J. Brill, Leiden 1991, 60.

26 G. R. Berridge, British Diplomacy in Turkey, 1583 to the Present; A Study in the Evolution of the Resident Embassy, (Leiden and Boston, Martinus Nijhoff Publishers, 2009), 75-76, 78.

27 For the full version of the convention see: Convention of Commerce and Navigation between Her Majesty, and The Sultan of the Ottoman Empire, Harrison and Sons, London 1839, 291-295. 
ic circumstances and potential of the region ${ }^{28}$. Sandison was not an exception, and he had over two decades of experience before he was appointed to the post ${ }^{29}$.

National firms operating in the Ottoman Empire were not considered as providers of commercial intelligence to the British Government as they were seen as reluctant to supply information for fear that it might encourage competition between possible competitors ${ }^{30}$. The role of consuls in the Levant was mainly to observe the commercial situation of the region. They were both diplomatic and commercial agents providing information for mercantilist activities, namely, acting as agents for the expansion of British trade ${ }^{31}$. Therefore, reports were essential for British manufacturers seeking raw materials from the Ottoman market or aiming to penetrate it with semi-finished or finished goods.

Great Britain, along with other European countries, had long followed the practice of maintaining permanent resident embassies and consulates ${ }^{32}$ in the Ot-

28 For the increasing commercial interest of Britain, relations, economic and political impact over the Levant Trade and changing attitudes of British Government see: Christine Laidlaw, The British in the Levant: Trade and Perceptions of the Ottoman Empire in the Eighteenth Century, (London: I.B. Tauris, 2010).

29 Secretary of State for Foreign Affairs, Lord Viscount Palmerston maintained the idea that the duties of consuls did not require a particular previous education and could be carried out by any man of good sense, See D. C. M. Platt, The Cinderella Service, British Consuls since 1825, (London, Longman Group limited, 1971), 21-25.

30 Ibid, 499.

31 British consuls were engaged in a wide range of activities to collect information on economic and trading capacities and changes in their region. Reports were prepared on current and changing economic conditions of the Ottoman Empire, taxation, customs regulations and tariffs etc. They also provided information on the trading capacity of certain regions of the Empire, export and import volumes over years, natural resources, population, and trading and legal procedures in the region. Reports presented information on the position and strength of British merchants as well as other European competitors and their merchants. See Uygur Kocabasoglu, Majestelerinin Konsoloslari, Ingiliz Belgeleriyle Osmanli Imparatorlugu'ndaki Ingiliz Konsoloslari (1580-1900), (Istanbul, Iletisim Yayinlari, 2004), 200: “.... British consuls had always been expected to prepare an annual report on the trade and navigation of their particular districts, and they were also instructed to report any new developments or matters of immediate commercial interest when they arose..." For a detailed assessment, see Platt, The Cinderella Service, British Consuls since 1825 , 104.

32 "Having an agent as a consulate in an Ottoman city was recognised as a part of right provided to the country of the consul with the capitulation treaty concluded with the Ottoman authorities. Consuls in the Ottoman cities could not be imprisoned for any reason and their houses could not be sealed as they were under the protection of the Ottoman State. The empire gave berats showing the positions of duties and rights and dignities of the consuls, as a sign that they approve 
toman capital as well as in some port cities or inland cities with certain industries. However, Bursa was not unknown to European merchants and associated with silk production, it was only with the Anglo-Ottoman Commercial Convention of 1838 that an English consul was appointed there.

\section{Donald Sandison's Attempts to Gain a Consular Post in Bursa}

Donald Sandison was interested in obtaining a consular post and applied for the post of consul at Salonica. He consulted to Sir John Ponsonby, Ambassador at Istanbul, as

...I intreat your Lordship's indulgence for addressing you on the subject having prepared the draft of an application to Lord Palmerston. I venture to submit it to your Lordship for perusal if not trespassing on his leisure, and believe that under the present state of the establishment at Salonica if might present some satisfactory grounds for the restoration of the consulship if not already determined upon the case... ${ }^{33}$

However, Charles Blunt, a member of the Levant service, was appointed consul in Salonica in January $1835^{34}$. After Charles Blunt was appointed, Sandison persuaded Lord Ponsonby, ambassador at Istanbul ${ }^{35}$, to recommend him to Lord Palmerston as consul of Bursa. Ponsonby prepared a letter to Lord Palmerston recommending Sandison to the Foreign Office by inferring his knowledge and capacity. He suggested that contact with local authorities and producers to be of benefit

the appointments of the consuls. These berats were signified that consuls were exempted from the customs duties. Consuls just like their ambassadors could use a person as their interpreter. The consuls were given 2\% of commission for export and import with the vessels under their flags. Any ship, carrying a flag of a state, could not leave the port without the permission of the consul in the city..." (Mubahat S. Kutukoglu, Ahidnameler ve Ticaret Muahedeleri, Osmanli Ansiklopedisi, Vol. III (Ankara, Yeni Turkiye Yayınları, 1999), 331. For a detailed assessment for berat and beratli (holder of a berat) see: The Encyclopaedia of Islam, Vol. I, 1170-1171.

33 Durham University Library, Archives and Special Collection, GRE/E/546/5, Draft Letter Sandison to Palmerston applying for the Post of Salonica, November 10, 1834.

34 Charles Blunt was a London merchant. His father, John Blunt, was a merchant and freeman of the Levant Company. Charles Blunt served as consul of Salonica between 1834 and 1856 when he was appointed as consul at Izmir. His son, Sir John Elijah Blunt, followed his father and became consul at Monastir and Skopje. He married Fanny Janet Sandison, the youngest daughter of Donald Sandison.

35 The British Ambassador in Istanbul already had the right to appoint consuls in some cities which were strategically important for British trade before the abolition of the Levant Company, FO, 78/135, Consular Establishment in the Levant, A letter to Canning from Cartwright, October 10, 1825. 
to the British government despite the consular $\cos ^{36}$. However, although Ponsonby strongly supported Sandison's appointment, extending the consular establishment was considered implausible at the time due to the costs.

Although there was no attempt by the Foreign Office to establish a consulate at Bursa, Sandison continued to try to persuade the authorities, both in Great Britain and in Istanbul. He prepared a memorandum on Bursa's trade and on the importance of the city as a station for a British consular agent. This memorandum must have had an effect on the Foreign Office-Lord Palmerston asked John Cartwright, Consul-General at Istanbul, to report his opinion on the issue ${ }^{37}$. According to his report to the private secretary at the Foreign Office, Bursa held an important position for the export of British yarn. However, the Commercial Convention of 1838 must have been the most influential factor in establishing a consular position at Bursa as the duration between the earlier rejection and the final decision to establish the post was only three months.

A British traveller, Edmund Spencer, provides some information on how the city of Bursa was considered in terms of manufacturing and commercial activities in 1830s:

... Some of the European travelers defined Bursa as an important industrial center and it was seen as [the] Manchester or Lyons of the Ottoman Empire. ... [T] he majority are engaged in commercial pursuits and manufactures, particularly of silk and cotton, Prusa being in this respect the Lyons and Manchester of Turkey... ${ }^{38}$

In a memorandum in December 1837, Sandison proposed that the Foreign Office establish a British consular position at Bursa ${ }^{39}$ : "Lord Palmerston thought

36 "Mr Sandison has written to me to beg that I would recommend him to you for your favourable consideration of his solicit to be approved Consul at Brussa. I think him a very intelligent man \& a good friend of the Liberal [faith]. I am sure he is remarkably well acquainted with this country $\&$ that he has peculiar advantages for property \& extending his present knowledge through the means of his connection by marriage with the Armenians", FO, 78/329B, July 16, 1835.

37 FO, 78/335, March 21, 1838, 44-46.

38 Edmund Spencer, Travels in the Western Caucasus, including a Tour through Imeritia, Mingrelia, Turkey, Moldovia, Galicia, Silesia, and Moravia, in 1836, Volume II, (London, Henry Colburn, 1838), 160.

39 After the British Foreign Office had been established, a consular post was the natural outcome of the commercial activities and commercial experience would have a direct effect for a nominee for a consular post as on selection. Some posts were created for trading and some for political purpo- 
it would be advisable Mr. Cartwright's opinion however was not so favourable."40 Civil servant John Backhouse wrote to Sandison that regarding the "...establishing of a British Consular agent at Brusa, [it] does not appear to his Lordship to render it expedient at present to incur the expense (?) of such [an] appointment." ${ }^{41}$

From the private letters of Donald Sandison it can be understood that he was very familiar with the political conditions and uncertainties of the Ottoman Empire and other players, such as Russia. He gave his political opinion on Russian expansion on the Ottoman dominions, especially into the Bosphorus, and its important consequences for the navigation of the two straits by British commercial vessels. He gave a detailed analyses of the Convention of Hunkar Iskelesi ${ }^{42}$, on how Russia exercised predominance in the Ottoman dominions and how this concerned the British authorities as well as British subjects who were carrying out commercial activities. He suggested the action that British authorities should take against this convention as well as what to do should Russia exercise the right the convention allowed ${ }^{43}$.

\section{The Last Post of Donald Sandison: An Appointed Consul at Bursa}

A search of the British National Archives reveals letters written to the Foreign Office, the Ambassador at Istanbul and also the Consul-General, which show Donald Sandison's keenness to obtain the consular post at Bursa.

ses. Bursa, in this sense, was a commercial post along with Salonica and Izmir; however, Trabzon was a political post (against Russia) despite being a port city and engaged in trade. For a detailed assessment see: The House of Commons, Report from the Select Committee on Diplomatic and Consular Services; together with the Proceedings of the Committee, Minutes of Evidence, 314, July $16,1872,9$.

$40 \quad$ FO, 78/339, 1838, 359.

$41 \quad$ FO, 78/339, 1838, 355.

42 The Convention of Hunkar Iskelesi was signed between the Ottoman and Russian Empires in 1833. It provided military aid to the Ottoman army for solving the conflict in Egypt against Mehmet Ali Pasha. The Ottoman authorities guaranteed to close the Dardanelles to foreign ships in the time of war. Originally, English vessels were granted the privilege of commerce in the Black Sea with an act of 1799; this act was confirmed by the Convention of 1809 . For a detailed assessment see: Parliamentary Papers, House of Commons, List of Treaties of Commerce and Navigation between Great Britain and Foreign Powers, Containing Most-Favoured-Nation Clauses, Commercial No. 30, (London, Harrison and Sons, 1883), 43; Parliamentary Papers, House of Commons, Treaties and other Documents Relating to the Black Sea, the Dardanelles and the Bosphorus: 1535-1877, Turkey No. 16, (London, Harrison and Sons, 1878), 19.

43 Durham University Library, GRE/E546/31, Observation on the Right of British intervention in the Affairs of Turkey, September 18, 1835, 16-24. 
Eventually, Sandison was appointed as British consul at Bursa in November 1838 at the age of forty-three ${ }^{44}$. On November 22, 1838, Lord Palmerston sent a letter to Sandison informing him of the decision and giving full directions and guidance on further steps. In this letter, Lord Palmerston clearly stated the aims of a consular post in the Levant by explaining to Sandison his precise duties ${ }^{45}$.

The consular post was also officially confirmed by the Foreign Office on October 29,1838 , mentioning his salary of $£ 300^{46}$ a year, $£ 100$ outfit allowance ${ }^{47}$ and liberty to engage in mercantile pursuits ${ }^{48}$. Besides being consul with certain rights, some consuls in the Ottoman Empire benefited from certain privileges in their region, such as developing private relations with some Ottoman officials, having the advantage of being exempt from some customs for their own products and permission to carry on private business ${ }^{49}$.

Donald Sandison was in London at the time of appointment and he was informed at his London office. He openly expressed his ideas to Lord Palmerston in a letter dated December 5, 1838 saying:

44 'The Queen Has Been Graciously Pleased to Appoint Donald Sandison, Esp. to be Her Majesty's Consul at Broussa', The London Gazette, Tuesday November 20, 1838, 4. Platt mentions that entry to the consular service in the nineteenth century was usually at an age between twenty-five and fifty. Promotion was neither by seniority nor by merit, and no guarantee against interlopers (Platt, The Cinderella Service, British Consuls since 1825, 48, 49.

45 “....your duty is to avail yourself of every favourable opportunity for collecting and transmitting to me any useful and interesting information relating to commerce, navigation, agriculture, and any other branch of statistics... You will receive a salary of $£ 300$ a year, commencing 10 days previously to the day of your embarkation, and permission is given to you to engage in mercantile pursuits. You are however to understand that you will not be entitled to any pensioner allowance upon the termination of your services under this Department”, FO, 78/339, 1838, 361-367).

46 The same documents listed merchant-consuls and their salaries adjacent to Bursa. According to that, Britain was represented with a consul in Salonica, Candia and Lyra and the salary was equal to $£ 300$ a year. However, Trebizond was represented with a vice-consul; the salary was equal to $£ 300$ since it involved taking a political and strategic position. On the other hand, the consuls in Edirne and Athens received $£ 200$ and $£ 250$ a year, respectively. This is an indicator of the purchasing power in these cities which shows the extent of economic activities. FO, 78/339, 1838, 359-360.

$47 \quad$ FO, 78/339, 1838, 358-359.

48 FO, 78/339, 1838, 357; "Salaried consuls permitted to trade, perhaps the majority after the 1831 economies but a decreasing minority after 1858 , were denied any pension right, presumably on the grounds that they could apply the profits of their trade to a private insurance..." (Platt, The Cinderella Service, British Consuls since 1825, 46).

49 Parliamentary Papers, Accounts \& Papers, Volume 60, 1872, 4. 


\section{EMINE ZEYTINLİ}

...Considering it might be for the general interests of British commerce at Brussa, as well as for my personal advantage in forming mercantile concecises (?) and gaining knowledge of matters essentially relating to the trade to pay a short visit to Manchester and Liverpool and some of the manufacturing places in their vicinity ${ }^{50}$.

His visit took about a month and on January 10, 1839 he notified Lord Palmerston that he was ready to take his commands for the consular post and to proceed to Bursa as well; he requested an interview with Lord Palmerston prior to his departure ${ }^{51}$.

In June 1839, Sandison informed Lord Palmerston that he had obtained the Ottoman berat and exequatur ${ }^{52}$ at Istanbul and shown all the instructions to the Ambassador and the Consul-General. He also informed the Foreign Office that he had started to deal with how the Commercial Convention of 1838 was to be put into operation in Bursa and that he had met the mütesellim ${ }^{53}$ concerning the convention ${ }^{54}$.

Archival documents reveal Sandison's correspondence about the application of the convention and his efforts to respect British commercial rights and privileges. His early reports to the Foreign Office show that the convention was not put into practice immediately in Bursa and its vicinity; local authorities were reported to be resistant because they were not informed about the privileged commercial position of British subjects. His letter of November 15, 1839 mentioned no change in the status of the convention and Sandison himself, as the consul of the province, reported that he was in close contact with newly appointed local governor ${ }^{55}$.

\section{Long-Lasting Consular Position}

Sandison was Consul of Bursa for three decades from November 1838 to September 1868 and he died in the post. However, the position was not intended to

$50 \quad$ FO, 78/339, 1838, 378-379.

51 FO, 78/367, 260.

52 A legal document allowing a foreign officer to exercise his duties.

53 A senior Ottoman officer, tax collector on behalf of the governor in Ottoman provinces before the 1839, see Yucel Ozkaya, "Mütesellim”, Türkiye Diyanet Vakfi İslâm Ansiklopedisi (DİA) (Ankara, Türkiye Diyanet Vakf1, 1999), Volume 32, 276. 203-204.

54 FO, 78/367, June 17, 1839, 262-263; Parliamentary Papers, House of Commons, Correspondences Relative to the Continuance of Monopolies in the Dominions of Turkey, Presented to the House of Commons by the Queen's Command, in pursuance of their Address of the 25th February, (London, T. R. Harrison, 1840), 41.

55 FO, 78/367, June 17, 1839, 282-283. 
be just for a limited period; there were other consuls/vice consuls who held the post for longer than Sandison. Sandison's long period as consul should, nevertheless, be considered a success. It is clear from reports over 30 years that he tried to make local authorities, custom operations in his district to act in accordance with the Commercial Convention of $1838^{56}$.

He acted to protect British merchants as well as local merchants under the British protection, including their business operations, carrying import items to certain districts and having local products transported to port cities to be exported. However, Sandison reported the economic and political ${ }^{57}$ situation of the region, as expected. Comparing it to other regions and their consuls, he reported accurately on daily practices, weather conditions and their effects on agricultural crops, some epidemics, earthquakes, police proceedings within his jurisdiction, the gradual increase in European products, together with the British cloth, twist, yarn, etc. He replied promptly to requests with detailed information concerning the subject of the report. He reported precisely on the prices of different crops and changes in crops, and projections on production in agriculture and manufacturing. Foreign Office document suggest Sandison's periodic reports and correspondences to be bulky when compared with other British consuls. Sandison claimed that his detailed reports published for the use of parliament pleased the government which attributed him with distinction $^{58}$.

He reported to the Foreign Office the prosperity and buying capacity of his consular district for British commodities being depending on 'the value and amount

56 Sandison reported to the Foreign Office some attempted abuse on the part of the local authorities in contravention of the Commercial Convention of 1838. For a detailed assessment see: FO, 78/532, February 20, 1843, 69-75; “...the difficulty of controlling the local officers so as to confine them to the proper rate and amount of Duties without adding other imports, as even now occasionally practised...", FO, 78/532, December 9, 1843, 136-137; FO, 78/570, July 8, 1844, 233.

57 He reported the changes and effects of the Ottoman government's decisions in the city; for example, see his reports on the declaration of Hatti Serif. FO, 78/1209, March 5, 1856, 81; FO, 78/1209, June 16, 1856, 206-207.

58 "Her Majesty's Government has for years been pleased to assign a copious place in especial to my periodical Reports and Returns often in extenso...", FO, 78/1398, December 12, 1858, 200); Platt claimed that due to foreign competition in the nineteenth century, more emphasis was given to "special reports on particular developments containing immediate suggestions for the expansion of British trade" than on routine annual reports. Sandison's reports must, therefore, have been invaluable in reflecting immediate changes and developments (Platt, The Cinderella Service, British Consuls since 1825, 104). 


\section{EMINE ZEYTINLİ}

of the silk products' that he spent some of his exertions of improvements of this product $^{59}$. Sandison's correspondence and reports clearly points to the success of the consular post and that British products found new markets in Turkey's interior ${ }^{60}$. He reported French, Swiss, Saxon, Italian, and Belgian sales in general. He also reported on Russian merchants, agents and consular work and he presented them as competitors who should be monitored carefully.

Sandison reported in the first year in his post that:

The establishment of the Consulate here has tended to the protection and extension of British Commodities in their circulation in this quarter by ensuring them from any secondary or local duties which the authorities in the Interior were occasionally in the habit of carrying levying for their own benefit...

However, he also wrote that he kept himself occupied in collecting information and sending returns on Bursa's trade:

...I have found difficulties in so doing from the reluctance of the Turkish authorities to give access in their registers or Extracts from them such a desired. And the imperfection of the records, in other cases their being entirely wanting in respect to Import Goods which have already paid the duties at the Capital and are not subject to any on this side. Under these circumstances I am resorting to every means of information, and I shall digest and prepare the same in proper form ... to be forwarded to your Lordship as early as possible $^{61}$.

59 "I have suggested to the peasantry and others engaged in it the simplest means by which with additional care in the nurture of the worms immense numbers of them which perish might be preserved, and [...] my suggestions to the sorting and winding off the Cocoons so that even with the simple and rude implements used they may obtain a far superior quality of silk.", FO, 78/402, January 10, 1840, 172-173.

60 "From the best information I can collect the consumption of British Manufactures during 1840 has been extended 20 to 25 per cent in the amount supplied from this market. The number of shops in the Bazars engaged in their sale has increased from 160 up to 200 and a greater quantity of our Goods has been consumed within the District, as well as circulated from hence to other parts of the interior... the use of cotton articles has been more extensively adopted and the general sale of British commodities promoted...", FO, 195/113, February 15, 1841, 81-82. An earlier report dated March 1838 mentioned that "... Bursa may not be ranked as a general market for British manufactures, the sale of which has hitherto been considered to be confined to the wants of the inhabitants of the city, and those of the immediate vicinity.", FO, 78/335, March 21, 1838, 44-46.

61 FO, 78/402, January 10, 1840, 169-170. 
Upon his arrival in Bursa, Donald Sandison realised that the Commercial Convention of 1838 was not being implemented - even the local authority was not informed about the convention and it was not willing to consider any proceedings, despite the imperial berat Sandison received from the Sultan ${ }^{62}$. However, some of Sandison's reports mentioned that he was working on this by meeting the local authorities etc. Finally, he reported to the Foreign Office in August 1839 that the convention had been put into operation in his district and that he had managed to abolish monopolies ${ }^{63}$. He also informed the Foreign Office in September 1839 that free transportation of Bursa silk by land to Izmir by the English and French was permitted ${ }^{64}$. It should also be considered as an achievement for the best interest of British merchants ${ }^{65}$.

Another of Donald Sandison's achievements was on custom duties. His reports show that he dedicated himself and ensured British merchants and produce enjoyed the privileges granted by the convention ${ }^{66}$. Some Ottoman archival documents

62 “... stated to the Mutselim (Mütesellim) that I was instructed to consider the recent Commercial Convention between Great Britain and the Porte as operative from the $1^{\text {st }}$ of March last and that it would be my duty in all cases where its provisions were not observed to adopt certain formalities prescribed to me although until he the Mutselim received orders from His government to put the Treaty in force, he was not to regard any proceeding of this nature as involving any personal responsibility on his part", FO, 78/367, June 17, 1839, 263.

63 "...It is satisfactory for me to add that no monopolies now exist within this District nor any duties or restrictions whatever on British trade contrary to our Treaties", FO, 78/402, September 4, 1840, 235-236); Parliamentary Papers, Correspondences Relative to the Continuance of Monopolies in the Dominions of Turkey, 41, 49.

64 Parliamentary Papers, Correspondences Relative to the Continuance of Monopolies in the Dominions of Turkey, 42; For a detailed analysis of the convention see: Mubahat S. Kutukoglu, Osmanli-Ingiliz Iktisadi Munasebetleri (1838-1850), Vol. II, Edebiyat Fakultesi Basimevi, Istanbul 1976, 7-42.

65 Earlier, the Ottoman government officially declared that Bursa's silk and silk products were not allowed to be sold by any local or foreign merchants before the need of the capital was fulfilled. For a detailed assessment see: Prime Ministry Archives (henceforth "BOA"), Cevdet, Hariciye Collection (C..HR..), 103/5147, 21/N /1216, "Bursa ...hasll olan ipekler ...kimseye satılmayıp tamamen Bursa bezestanına nakil olunup Istanbul'a lüzumu olan mikdarı alınmadıkca yerli ve ecnebi kimseye ipek sattırılmayacağına dair Nemçe, Prusya, İspanya, İngiltere, Sicilyateyn, İsveç, Danimarka sefaretlerine ve Dubrovnik konsolosu...verilen takrir."

66 “...the custom duty partially levied on British Goods has been entirely suppressed, and struck orders given by the chief local authorities as they inform me that not a piece of British Manufactures be hence forth subject to it.", FO, 78/402, May 15, 1840, 214; “...the Saxon Manufacturers have commenced making Imitations of the Brussa Silk and Cotton Stuffs used for Dresses which if carried to the extent which the success of their introduction encourages would greatly interfere with British and local Manufacturers...", FO, 195/113, February 15, 1841. 
concern custom duties; foreign, British and berat holder local merchants, as well as the consul himself, could not be exempt from the duties. An official letter addressed to the Governor of Bursa stated that the consul himself was not exempt from duties for his private businesses for the reason of being the consul; he was subject to the same amount that a British subject paid ${ }^{67}$. The same document concerns some merchants in the districts of Bandirma and Erdek acting as Vice-Consul without a decree (emirname); the position of these merchants was to be decided by the consul of Bursa ${ }^{68}$.

The only document revealing the disapprobation of the Foreign Office concerned Sandison's recommendation for the consular agent at Mudanya during his last year in the post. In this letter, Sandison explained that his prolonged illness had prevented him from informing the Foreign Office and from acknowledging receipt of Lord Stanley's letter. Sandison also explained his regrets and the reason for recommending a consular agent ${ }^{69}$.

Few documents in the Ottoman archive refer to Consul Donald Sandison, but one is on his actions against the condition within the convention: minutes sent from the city council of Bursa to the government and then documented to the foreign minister in $1845^{70}$. However, the document does not mention the Consul's actions

67 “...zatına âid bazı eşyadan resm-i gümrük alınmamak ve sâir bazı imtiyâzâta nâil olunması hâiz olmayacağına mebni bu dakikalara ser-nazar-ı dikkat ile bir minvâle muharrer merkumun yolunda ve nizaminda vuku' bulacak ifadatın min-gayr- $i$ resmi kabule ve tesviyyesine bakllması lazım geleceği malum olduğuna icra buyrulması...”, BOA, Hariciye Nezareti, Mektubi Kalemi Collection, (HR. MKT.), 75/53, 27/B /1270.

68 “... konsolos vekili tanınmasına dâir mahallince bir günâ malumat olmadiğı beyânıyla bunlar hakkında ne-vechile muâmele olunması lâzım geleceği isti 'lâmını hâvi Erdek kâim-makâmı bize--- - savb-ı çâkeriyye bir kit 'a şukkası lede'l-vurud mersum Enrunaki'nin vekaletini keyfiyyetini devlet-i müşarün-ileyhanın Burusa'da mukim konsolosu tarafindan tercüman vasitasıly sual ve istiknah olundukta...”, BOA, HR. MKT., 75/53, 27/B /1270.

69 "I beg leave to explain that I was not unmindful of the Rule referred to by his Lordship but which had not been observed in practice in the case of the dependent stations in my Consulate. The Vice Consul at Ghio and Consular agent at Panorama were both ignorant of English as like wise Mr. Galle the late agent at Mundania, who had been recommended by me with the previous asset of Sir Henry Bulmer and it was in view of those antecedents that I made the application in favour of Mr. Lombridi, whilst Lord Stanley's disapprobation on the occasion...", FO, 78/2048, August 24, $1868,217$.

70 “Mahruse-i Burusa'da mukim Ingiltere konsolosu Sandison nam müste'minin muğayir-i uhud ve şurut-ı hâlâta cür'et etmekte olduğu beyânıyla icrâ-yı icâbı hususuna dâir Burusa mahallesinden tevârüd eden bir kıt'a zabıt leffen tesyir ----- kılınmış derhal mazbataya nazar ve icrâ-yı icâbı ------- bulunmuş olmağın olbâbda”, BOA, C.HR., 155/7705, 29/Ca/1261. 
precisely, and such an occurrence has not been found in any of Sandison's correspondence during the relevant time period or in Foreign Office dispatches sent periodically to British consular officers. Moreover, in one correspondence, in 1858, Sandison sent an acknowledgment to the Foreign Office upon receiving a circular. He reported that he was paying strict attention to avoiding quarrels with the authorities of the Porte, was abstaining from forcing any discussion, and treating the Ottoman authorities with respect and having amicable relations ${ }^{71}$. Donald Sandison was also reported to be a quick-tempered person and not to be fair to those asking for an internal passport to travel to Istanbul in $1848^{72}$.

One correspondence between Bursa and the Foreign Office indicates a debate about abolishing the consulate of Bursa together with $\mathrm{Jaffa}^{73}$. The reply and reaction of Donald Sandison reveals useful information about how he attributed importance to the commerce of Britain in Bursa. He asked why Bursa should be coupled with the inconsiderable station of Jaffa and how this conclusion was reached ${ }^{74}$. Sandison's response provides some information about how he carried out his duty over the years. He mentioned how the British government was pleased with his reports and that he had received honourable approbation from the government and embassy. He also mentioned that reducing the status of the consulate to a vice-consulate would not serve the best interests of the country and would impair the efficiency of the officer ${ }^{75}$. Moreover, he reminded the Foreign Office that cotton cultivation had greatly increased in the city and therefore a consul should be stationed in the places where the chief local authority resides ${ }^{76}$. He concluded by mentioning his diligent

71 FO, 78/1398, December 22, 1858, 213-214.

72 BOA, HR. MKT., 26/53, 03/Ş/1265.

73 A recommendation to revise the consular position and right of various consuls in the same year (1858). The recommendation in respect of Donald Sandison was to restrict him from trading and materials and to increase the salary. The current salary was cited as $£ 350$; however, it was actually $£ 300$ and $£ 100$ for office expenses. The proposed salary was not calculated for this post. For a detailed assessment see: Correspondence on the Subject of the Report of the Consular Committee of 1858, (London, Harrison and Sons, 1860), 20-24.

$74 \quad$ FO, 78/1398, December 12, 1858, 199.

75 "...for the nature of the duties here, and the grave emergencies to arise, it would not be conducive to the interests of Her Majesty's service to reduce the consulate at Brussa to a vice consulate, and thus impair the weight and influence of the officer in charge, as possibly also his efficiency.", FO, 78/1398, December 12, 1858, 203.

76 FO, 78/1398, December 12, 1858, 203. 
efforts as a consul, preparing valuable reports etc. ${ }^{77}$ In short, Sandison retained his position until he died and the consular post was demoted to vice-consul status within the appointment of the new consul in 1869.

Donald Sandison mainly resided in Istanbul where he carried out his business operations; after he was appointed consul at Bursa he became resident there and used his annual leave to go to Istanbul either for private business, public affairs or, in later years, medical advice. He each time reported his absence through a licence from the ambassador which was something necessary in accordance with the Foreign Office rules. When he left his post for some days because of private interests, he called them 'for private interests and these of our trade ${ }^{78}$ ' or 'on matters connected with the public service and private affairs ${ }^{79}$.' However, he had connections with Great Britain and was in London when he was appointed as consul and so he requested to stay there a few more weeks to conduct his private business. He was later in London again in 1859 for the wedding of his daughter ${ }^{80}$. According to his daughter, Fanny Blunt, his two children were educated in London for two years ${ }^{81}$.

Sandison's salary was decided at $£ 300$ and an annual allowance. In December 1855 he demanded a permanent increase in his salary due to an increase in the cost of living in Bursa. The permanent increase in his salary was not accepted by the Foreign Office. However, considering the increase in the cost of living and consequent upon the state of war, an extra personal allowance of $£ 200$ a year was granted to him

77 "Her Majesty's Government has for years been pleased to assign a conscious place in especial to my periodical reports and Returns often in extensor, in the relation of those Vice Consuls in Turkey published for the use of Parliament, and thus various to the Country... it has been satisfactory for me to have received the most honourable approbation of my proceeding a Report", FO, 78/1398, December 12, 1858, 200-201.

78 He left in June 1843 for five days and for 15 days in July 1843, FO, 78/532, 110, 114; in August 1845 he left for 13 days, FO, 78/612, 316).

79 He left in July and August 1844 for 19 days, FO, 78/570, 261, in May and June 1856 for 13 days, FO, 78/1209, 211); in July 1856 for 13 days, FO, 78/1209, 245); in September 1858 for 15 days, FO, 78/1398, 138); in December 1858 for 23 days, FO, 78/1398, 217); in May 1863 for a few weeks, FO, 78/1863, 79); in June 1863 for a few weeks, FO, 78/1863, 83); and for two months in June and July 1867, FO, 78/1986, 210, 216).

80 His name appears as registered in the Post Office London directory which covered official, commercial, court, parliamentary, postage and banking directories. Sandison's name was listed as British Consul at Bursa, The Small Edition of the Post Office London Directory, (London, W. Kelly \& Co, 1843, 59).

81 Blunt, My Reminiscences, 48-49. 
in addition to his regular salary ${ }^{82}$. In 1859 , Sandison again requested a permanent increase but it was not accepted ${ }^{83}$.

Sandison suffered from "tic douloureux' and left his post for some weeks for medical advice in Istanbul ${ }^{84}$. He died on September 6, 1868 in Bursa and his death was reported by his son, Alfred Sandison, acting consul at Bursa, to the foreign office from Istanbul on December 16, the same year ${ }^{85}$. Alfred Sandison was the acting consul until John Frederick Albany Maling, a non-trading officer, was appointed Vice-Consul to Bursa on November 24, $1869^{86}$.

\section{Conclusion}

Donald Sandison worked for the East India Company and was a privileged member of the Levant Company before he was appointed to the consular post at Bursa. Increasing level of economic activities between Britain and the

82 FO, 78/1209, February $12,1856,2-3,12,213$. This additional allowance of $£ 200$ was requested to be extended to the year 1857, FO, $78 / 1209$, July 12, 1856, 231). This annual payment must have been considered as a temporary allowance by the Foreign office as Sandison was informed to have another allowance of $£ 100$ a year for office expenses in 1860, FO, 78/1534, April 7, 1860, 101). However, no documents exist on such an allowance for the years between 1857 and 1860 .

83 “...intimating that your Lordship had not found sufficient reason to accede to my request for an increase of salary.”, FO, 78/1859, October 29, 1859, 251). The Foreign Office must have been aware of the low payment of consuls: Edmund Hammond, Permanent Under-Secretary, reported that "...the general feeling in the Foreign Office is that our consular service is miserably paid, and we should be very glad indeed...", Second Report from the Select Committee on Diplomatic and Consular Services: Minutes of Evidence, 380, 1871, 11.

84 “...on the benefit of my health, on account of a severe return of tic douloureux...", FO, 78/1302, 398); Sandison left for two to three weeks (19 days) at the beginning of 1856, FO, 78/1209, January 23, 1856, 56, 146); he left for 12 days on August 5, 1857, FO, 78/1302, 398); he left for 29 days on December 31, 1859, FO, 78/1450, 294); and he left for 7 days in January 1860, FO, 78/1534, 99).

85 “...of my father, the late Mr. Consul D. Sandison who dies intestate at Brussa on the sixth of September last. Mr. Sandison having been resident at his post and in the execution of his duties as Her Majesty's Consul at Brussa during the greater part of the quarter ended on the 30th of September last, I venture to hope that it may please Her Majesty's Government to authorize the payment of the salary due upon that quarter in belief of the widow and of the other Heirs to the estate of the deceased of which I am now the administrator.", FO, 78/2048, December 16, 1868, 219-220.

86 Parliamentary Papers, House of Commons, Reports from Her Majesty's Diplomatic and Consular Agents Abroad, Respecting the Condition of the Industrial Classes in Foreign Countries, Presented to both Houses of Parliament by Her Majesty's Command, (London, Harrison and Sons, 1870), 2 . 
Ottoman Empire fostered his economic activities and consular posts. He was appointed to Bursa at a time of commercial and political upheaval. Sandison's business as a merchant in Istanbul probably shaped his family life. He married Mary Zohrab, daughter of Constantine Zohrab, a merchant and partner of Mr. John Cartwright, who had been the British Consul-General in Istanbul since 1817. Being part of a family that had a business partnership with the Consul-General must have had a positive effect since Sandison could directly correspond with high officials.

The British Levant Company, a charter company, carried out trading activities in the Ottoman dominions and Donald Sandison was one of the merchants who had settled in Istanbul and operated in the Ottoman Empire as a representative of the British East India Company from the beginning of the nineteenth century. $\mathrm{He}$ became a member of the Levant Company in 1817 and was a freeman of the Company. Sandison applied to be the Consul of Salonica in 1834, and his desire to be a consul was eventually realised four years later in 1838 at Bursa.

British subjects in the Ottoman Empire mainly resided in port cities and were not very active in inland cities of the country. Bursa is an interesting case in respect of the number of European consuls appointed there and of merchants who opened offices and operated in the city along with local merchants.

The importance of silk manufacturing in the European silk industry made Bursa a valuable centre for European and British merchants. The significance of silk in Ottoman manufacturing brought a great opportunity to Western traders in the clothing industry. It is noted that the appointment of Sandison in Bursa made a positive contribution to the export of raw silk, its competitiveness in international export markets as a raw material, and to Britain's silk cloth industry as finished goods.

Donald Sandison was an experienced member of the Levant service. Personal correspondence and archival documents suggest Sandison's professional ambitions and capacity, his over- eagerness to gain a consular post and his commitment to his appointment. He was a far-sighted merchant in preparing a memorandum for the Foreign Office and anticipating the expansion of the commercial potential of Bursa and the role of its consul. Some of his reports could be indicating that he had a political function as he also reported on political and social conditions of the region as well as his own concerns as a part of his regular reports. 
Peer-review: Externally peer-reviewed.

Conflict of Interest: The author has no conflict of interest to declare.

Financial Disclosure: The author declared that this research received funding from the Scientific and Technological Research Council of Turkey (TUBITAK), under the postdoctoral research scholarship programme.

Hakem Değerlendirmesi: Dış bağımsız.

Çıkar Çatışması: Yazar çıkar çatışması bildirmemiştir.

Finansal Destek: Yazar, bu çalışmanın Türkiye Bilimsel ve Teknolojik Araştırma Kurumu (TÜBİTAK)'nun doktora sonrası araştırma bursu desteğiyle gerçekleştirildiğini beyan etmiştir.

\section{References}

\section{Archival Documents}

\section{The National Archives}

Durham University Library, Archives and Special Collection, GRE/E/546/5, Draft Letter Sandison to Palmerston applying for the Post of Salonica, 10 November 1834.

Durham University Library, Archives and Special Collection, GRE/E546/31, Observation on the right of British intervention in the affairs of Turkey, September 18,1835 .

Foreign Office (FO), 78/135, Consular Establishment in the Levant, A letter to Canning from Cartwright. $10^{\text {th }}$ of October 1825.

FO, 78/329B, From Lord Ponsonby, July 16th, 1835.

FO, 78/335, Correspondence with Consul John Cartwright, Constantinople, 21 March 1838.

FO, 78/339, Ottoman Empire: correspondence with Consul Sidney Smith Saunders, Prevesa; Consul Colonel G Lloyd Hodges, Belgrade; Samuel Gardner, Jassy; Consul D Sandison, Broussa; Consul Charles Cunningham, Galatz, 1838.

FO 78/367, 17 June 1839. 
FO, 78/402, Sandison at Brusa, January 10th, 1840.

FO 78/532, February 20th, 1843.

FO 78/570, January 31, 1844: May, June 1856.

FO 78/612, July, August 1844.

FO 78/868, 1851.

FO 78/1209, January 23, February 12, March 5, 1856; June 16, July 12 1856; August 5 1857; September 30, 1858.

FO 78/1302, December 31, 1859.

FO, 78/1398, September 15, December 12, 22, 1858.

FO, 78/1450, January 1860 .

FO, 78/1534, April 7, 1860.

FO, 78/1859, October 29, 1859.

FO, 78/1863, June 1863; June, July, 1867.

FO, 78/1986, June 22, 1867: June 25, 1867.

FO, 78/2048, August 24, 1868; December 16, 1868.

FO, 195/113, February 15, 1841.

State Paper (SP), 105/211, Register of orders made by the General Court of the Levant Company, 1734-1818.

SP, 105/333, 1744-1824.

\section{State Archive of Turkey:}

Basbakanlik Osmanli Arsivi (BOA), Cevdet, Hariciye Collection (C.HR.)

BOA, Hariciye Nezareti, Mektubi Kalemi Collection, (HR. MKT.)

Berridge, G. R., British Diplomacy in Turkey, 1583 to the Present; A Study in the Evolution of the Resident Embassy, Martinus Nijhoff Publishers, Leiden and Boston 2009.

Blunt, Fanny Janet, My Reminiscences, John Murray, London 1918.

Catsiyannis, Timotheos, Contantine Ionidis Ipliktsis, 1775-1852 and The Ionidi Family, London 1988. 
Clarke, Hyde Henry, "The History of the British Colony at Smyrna", Levant Herald, 1860.

Convention of Commerce and Navigation between Her Majesty, and The Sultan of the Ottoman Empire, Harrison and Sons, London 1839.

Correspondence on the Subject of the Report of the Consular Committee of 1858, Harrison and Sons, London 1860.

Hamlin, Cyrus, Among the Turks, American Tract Society, 1877.

http://www.levantineheritage.com/pdf/Hyde-Clarke-by-D-Wilson-2015.pdf, accessed November 15, 2018.

Goudas, Anastasios N., Vioi paralliloi ton epi tis Anagenniseos tis Ellados Diaprepsanton Andron, Plots I Emporion, Vol. III, Athens 1970.

Kocabasoglu, Uygur, Majestelerinin Konsoloslari, Ingiliz Belgeleriyle Osmanli Imparatorlugu'ndaki Ingiliz Konsoloslari (1580-1900), İletişim Yayınları, İstanbul 2004.

Kütükoğlu, Mübahat S., "Ahidnameler ve Ticaret Muahedeleri”, Osmanli Ansiklopedisi, Vol. III, Yeni Türkiye Yayınları, Ankara 1999.

, Osmanli-Ingiliz Iktisadi Munasebetleri (1838-1850), Vol. II, Edebiyat Fakültesi Basımevi, İstanbul 1976.

Laidlaw, Christine, The British in the Levant: Trade and Perceptions of the Ottoman Empire in the Eighteenth Century, I.B. Tauris, London 2010.

MacFarlane, Charles, Constantinople in 1828, A Residence of Sixteen Months in the Turkish Capital and Provinces: with an Account of the Present State of the Naval and Military Power, and of the Resources of the Ottoman Empire, Second Edition, Volume 1. Saunders and Otley. London, 1829.

Özkaya, Yücel, "Mütesellim”, Türkiye Diyanet Vakfi İslâm Ansiklopedisi (DIA), Vol. XXXII, Ankara, Türkiye Diyanet Vakfi, 1999.

Parliamentary Papers, House of Commons, Correspondences Relative to the Continuance of Monopolies in the Dominions of Turkey, Presented to the House of Commons by the Queen's Command, in pursuance of their Address of the 25th February, T. R. Harrison, London 1840.

Parliamentary Papers, House of Commons, Reports from Her Majesty's Diplomatic and Consular Agents Abroad, Respecting the Condition of the Industrial 
Classes in Foreign Countries, Presented to both Houses of Parliament by Her Majesty's Command, Harrison and Sons, London 1870.

Parliamentary Papers, House of Commons, Treaties and other Documents Relating to the Black Sea, the Dardanelles and the Bosphorus: 1535-1877, Turkey No. 16, Harrison and Sons, London 1878.

Parliamentary Papers, House of Commons, List of Treaties of Commerce and Navigation between Great Britain and Foreign Powers, Containing Most-Favoured-Nation Clauses, Commercial No. 30, Harrison and Sons, London 1883.

Platt, D C M., The Cinderella Service, British Consuls since 1825, Longman Group Limited, London 1971.

Report from the Selected Committee on Consular Establishment; Together with the Minutes of Evidence, and Appendix. 22 ${ }^{\text {nd }}$ August 1835, Vol. 26.

Report from the Selected Committee on Diplomatic and Consular Services; together with the Proceedings of the Committee, Minutes of Evidence, The House of Commons 314, 16 July 1872.

Second Report from the Select Committee on Diplomatic and Consular Services: Minutes of Evidence, 380, 1871.

Sir Alexander Telford Waugh, Turkey, Yesterday, To-Day, and To-Morrow, Chapman and Hall's, London 1930.

Sir Edwin Pears, Forty Years in Constantinople, Herbert Jenkins Limited, 1915.

The Anglican Chaplaincy, The British Consulate of Istanbul, Register of Birth, Deaths and Marriages, from 1757 to 1840.

The Encyclopaedia of Islam, eds. B. Lewis, CH. Pellat, J. Schacht, Vol. I-II, E.J.Brill, Leiden 1991.

The Small Edition of the Post Office London Directory, W. Kelly \& Co, London 1843.

The Smyrna Anglican Chaplaincy, Baptism, Marriage and Burial Records of the British Chapel, Smyrna-Turkey 1800-1944. 